\title{
Two less common human microRNAs miR-875 and miR-3144 target a conserved site of E6 oncogene in most high-risk human papillomavirus subtypes
}

\author{
Lin Lin ${ }^{1}$, Qingqing Cai ${ }^{1,3}$, Xiaoyan Zhang ${ }^{5}$, Hongwei Zhang ${ }^{1}$, Yang Zhong ${ }^{6,7}$, Congjian $\mathrm{Xu}^{1,2,3,4 \bowtie}$, \\ Yanyun $\mathrm{Li}^{1 凶}$ \\ ${ }^{1}$ Department of Gynecology, Obstetrics and Gynecology Hospital, Fudan University, Shanghai 200011, China \\ 2 Department of Obstetrics and Gynecology of Shanghai Medical School, Fudan University, Shanghai 200032, China \\ ${ }^{3}$ Shanghai Key Laboratory of Female Reproductive Endocrine Related Diseases, Shanghai 200011, China \\ ${ }^{4}$ Institute of Biomedical Sciences, Fudan University, Shanghai 200032, China \\ ${ }^{5}$ School of Life Sciences and Technology, Tongji University, Shanghai 200092, China \\ ${ }^{6}$ Shanghai Center for Bioinformation Technology, Shanghai 200235, China \\ ${ }^{7}$ School of Life Sciences, Fudan University, Shanghai 200433, China \\ $\triangle$ Correspondence: xucongjian@gmail.com (C. Xu), helen.liyanyun@outlook.com (Y. Li)
}

Received December 22, 2014 Accepted January 28, 2015

\begin{abstract}
Human papillomaviruses (HPVs) including high-risk (HR) and low-risk (LR) subtypes have distinguishable variation on both genotypes and phenotypes. The coinfection of multiple HR-HPVs, headed by HPV16, is common in cervical cancer in female. Recently accumulating reports have focused on the interaction between virus and host, particularly the role of human microRNAs (miRNAs) in anti-viral defense by targeting viral genome. Here, we found a well-conserved target site of miRNAs in the genomes of most HR-HPVs, not LR-HPVs, by scanning all potential target sites of human miRNAs on 24 HPVs of unambiguous subtypes of risk. The site is targeted by two less common human miRNAs, miR-875 and miR-3144, and is located in E6 oncogene open reading frame (ORF) and overlap with the first alternative splice exon of viral early transcripts. In validation tests, miR-875 and miR-3144 were identified to suppress the target reporter activity markedly and inhibit the expression of both synthetically exogenous E6 and endogenous E6 oncogene. High level of two miRNAs can inhibit cell growth and promote apoptosis
\end{abstract}

Lin Lin and Qingqing Cai have contributed equally to this work. in HPV16-positive cervical cancer cells. This study provides a promising common target of miRNAs for most HR-HPVs and highlights the effects of two low expressed human miRNAs on tumour suppression.

KEYWORDS human papillomavirus, microRNA, E6, miR-875, miR-3144

\section{INTRODUCTION}

MicroRNAs (miRNAs) are small non-coding RNAs that modulate gene expression at post-transcriptional level for degradation of the target mRNAs or inhibiting translation of the encoded protein, playing critical roles in a wide spectrum of biological processes (Ambros, 2004). They bind to complementary target sites in mRNA that are often located in $3^{\prime}$ untranslated region (UTR) but can also be found in $5^{\prime}$ UTR or even coding region (Forman and Coller, 2010; Li et al., 2011). Recent data provide increasing evidence that human miRNAs may directly affect viral gene expression contributing to host's innate anti-viral defense or viral immune escape (Ghosh et al., 2009; Mahajan et al., 2009). In 2005, one human miRNA (has-miR-32) was reported to be able to target sequence in primate foamy virus type 1 (PFV-1) genome thereby inhibiting viral replication and translation 
(Lecellier et al., 2005). Currently, more and more human miRNAs that target hepatitis $C$ virus ( $\mathrm{HCV}$ ), hepatitis $B$ virus (HBV), human immunodeficiency virus (HIV), influenza $A$ Virus H5N1 and H1N1 were found (Houzet et al., 2012; Pedersen et al., 2007; Potenza et al., 2011; Scaria et al., 2006; Song et al., 2010). It is noted that many of these target sequences, such as the target of miR-125 in HBV, the targets of miR-448 and miR-122 in HCV (Li et al., 2011; Pedersen et al., 2007; Potenza et al., 2011), were found well conserved through viral genomes, and several of them have been preferentially exploited for new anti-viral strategies (Russo and Potenza, 2011).

Human papillomaviruses (HPVs) are non-enveloped, double-stranded circular DNA viruses and are associated with a wide spectrum of benign and malignant neoplasia (Zheng and Baker, 2006). Until now, more than 120 HPV subtypes have been identified and characterized (Bernard et al., 2010). According to oncogenic potentials epidemiologically, some of them are classified into "high-risk (HR)" group and "low-risk (LR)" group (Munoz et al., 2003). Persistent infection of multiple HR-HPVs is the major cause of cervical cancer in female. As a representative HR-HPV, HPV16 is responsible for approximately $\sim 60 \%$ of invasive cervical cancers worldwide (Zheng and Baker, 2006). HR-HPVs bound up with malignancies have developed many oncogenic strategies which are rarely found in LR-HPVs. Examples include that viral crucial oncoproteins efficiently degrade tumor suppressors (such as E6 target p53) (Scheffner et al., 1990), and integration of the viral DNA segments into the human genome increases E6 expression leading to oncogenesis (Alp Avci, 2012).

While the role of miRNAs in cervical cancer, as well as in other cancers, has been extensively studied during the past few years (Hayes et al., 2014; Jimenez-Wences et al., 2014), few miRNAs have been reported to be involved in the regulation of HPV viral life cycle, and those researches were based on limited HR-HPV subtypes (Gunasekharan and Laimins, 2013; Jung et al., 2014; Melar-New and Laimins, 2010; Nuovo et al., 2010). Since co-infection of multiple HRHPVs is common in cervical cancer (Mejlhede et al., 2010), we wondered that whether there are some human miRNAs who can target the majority of HR-HPVs. Our previous study found that HPVs in different group with specific oncogenic potential (HR or LR group) have distinguishable divergence on phylogenetic genotypes (Li et al., 2009). We also noticed that miRNAs are conserved, and are promising phylogenetic markers for interpreting evolution of organisms (Qingqing Cai, 2010). Therefore, it seems possible to find some candidate miRNAs and conserved target sites distinguishable between HR-HPVs and LR-HPVs.

In this study, we employed bioinformatics approaches to look for potential conserved target among the majority of HRHPV genomes for human miRNAs and investigate the target effects of candidate miRNAs on HPV oncogene and cervical cancer cells. It might provide a promising common target of miRNAs for most HR-HPVs and focus on the effects of two low expressed human miRNAs on tumour suppression.

\section{RESULTS}

In silico analysis yielded most promising target sites of human miRNAs in HPV genome

15 HR-HPV subtypes (HPV16, 18, 31, 33, 35, 39, 45, 51, $52,56,58,59,68,73$, and 82) and 9 LR-HPV subtypes (HPV6, 11, 40, 42, 43, 44, 54, 61, and 81) were obtained from PaVE: Papilloma virus genome database (http://pave. niaid.nih.gov/). Sequences were allocated according to genes and regions annotation and formed 8 representing regions including $E 1, E 2, E 4, E 6, E 7, L 1, L 2$, and URR which existed in almost all types of HPVs. The sequences of each gene or region were aligned by MUSCLE with default parameters. All sequences were subjected to scanning for the putative binding sites of 2042 human mature miRNAs by miRanda. Firstly, we calculated the presumed binding efficiency between HR-HPV group and LR-HPV group of each gene (or URR) region roughly: If a miRNA has (at least) one binding site on a gene part in one HPV subtype, we noted the binding situation as 1 (existing), otherwise we noted as 0 (none). Then binding efficiency was summarized according to HPV risk groups. For example, miR-4282 was predicted to bind L1 genes of 15 HPV subtypes. Then the binding efficiency of miR-4282 and L1 were recorded as 15 (13 for HR-HPVs, while 2 for LR-HPVs). Top 12 miRNAs who demonstrated a strong preference for either risk group (the utmost absolute difference between HR-HPVs and LR-HPVs) was listed in Table 1. In order to study the binding pattern, the binding sites of 12 selected miRNAs were mapped to HPV alignments. Amazingly, most of the binding sites were randomly located among HPVs or formed small conservation sites, while the potential targets of miR-875 and miR-3144 located in E6 oncogene ORF happened to form a conserved target site almost unique in HR-HPVs as was shown in Fig. 1. For HPV16, miR-875 was supposed to target segment nt 209-231 and miR-3144 was supposed to target segment nt 207-232. The detailed sequences were showed in Table 2.

\section{MiR-875 and miR-3144 target the HPV genomic sites in luciferase reporter}

As bioinformatics analysis yielded the most promising target sites of human miRNAs in HPV genome, it was important to determine if the seed sequences actually functioned as target for these miRNAs. The most common and direct methods for miRNA target validation are based on fluorescent reporter gene constructs transfected in cultured cells (Kuhn et al., 2008). The HPV genomic segments containing putative target sites for miR-875 and miR-3144 were then individually cloned downstream of the Renilla luciferase open reading frame contained in the psiCheck-2 vector as reporter. These luciferase reporters were subsequently transfected into C33A cells along with miRNA expression vectors and assayed for luciferase expression. The results obtained 
Table 1. Most differentiated binding situation between HR-HPV group and LR-HPV group

\begin{tabular}{|c|c|c|c|c|c|c|}
\hline Rank & Gene part & MiRNA & $\begin{array}{l}\text { Binding efficiency } \\
\text { of } 24 \mathrm{HPVs}\end{array}$ & $\begin{array}{l}\text { Binding efficiency } \\
\text { of HR-HPVs }\end{array}$ & $\begin{array}{l}\text { Binding efficiency } \\
\text { of LR-HPVs }\end{array}$ & $\begin{array}{l}\text { Absolute } \\
\text { difference }\end{array}$ \\
\hline 1 & E6 & MiR-875 & 13 & 13 & 0 & 13 \\
\hline 2 & E6 & MiR-3144 & 12 & 12 & 0 & 12 \\
\hline 3 & L1 & MiR-4282 & 15 & 13 & 2 & 11 \\
\hline 4 & $\mathrm{E} 1$ & MiR-2355 & 13 & 12 & 1 & 11 \\
\hline 5 & $\mathrm{E} 1$ & MiR-365 & 11 & 11 & 0 & 11 \\
\hline 6 & L2 & MiR-889 & 20 & 15 & 5 & 10 \\
\hline 7 & $\mathrm{E} 1$ & MiR-626 & 18 & 14 & 4 & 10 \\
\hline 8 & E2 & MiR-302a & 14 & 12 & 2 & 10 \\
\hline 9 & E2 & MiR-2355 & 14 & 12 & 2 & 10 \\
\hline 10 & E1 & MiR-26b & 12 & 11 & 1 & 10 \\
\hline 11 & L2 & MiR-3665 & 12 & 11 & 1 & 10 \\
\hline 12 & L1 & MiR-1299 & 10 & 10 & 0 & 10 \\
\hline
\end{tabular}

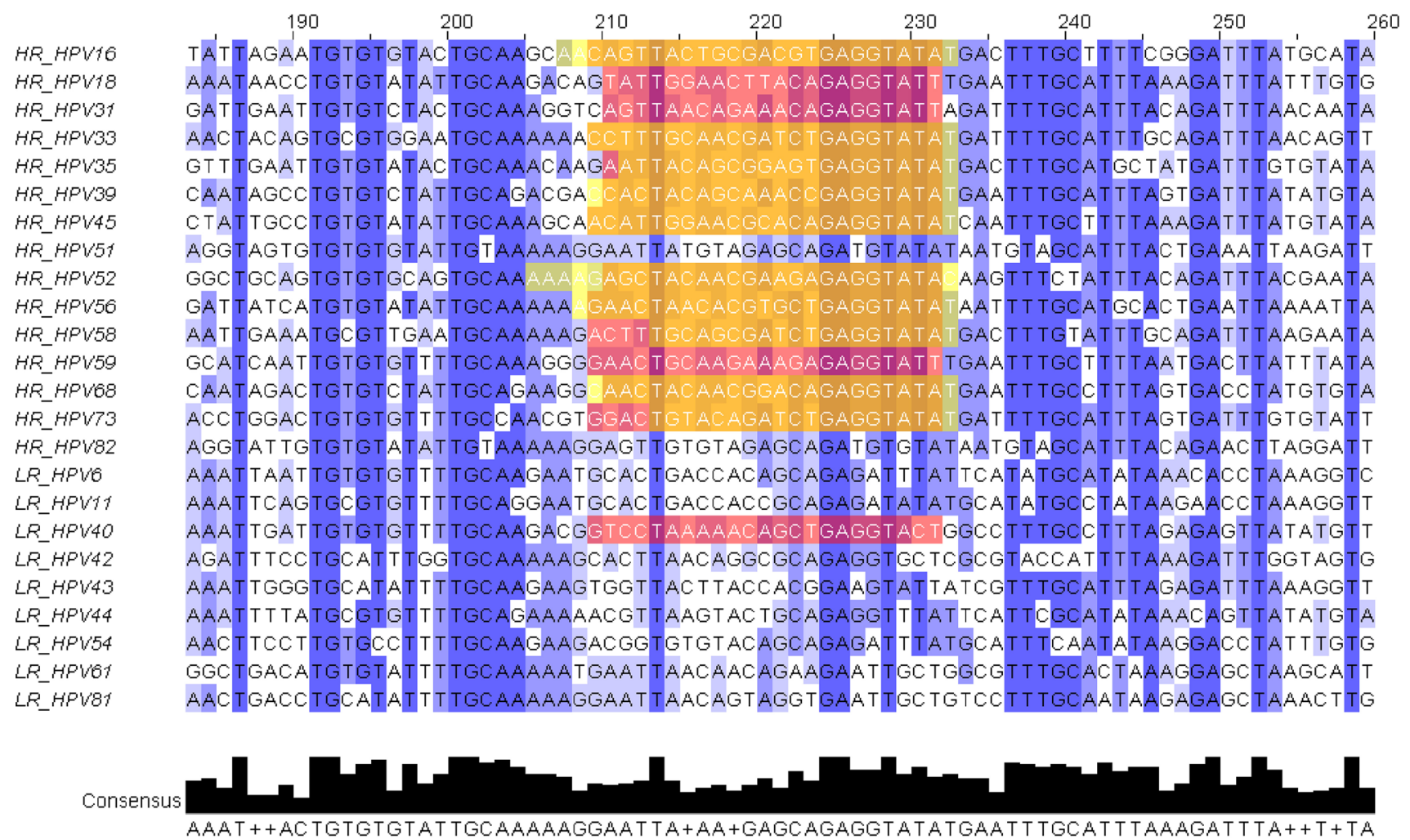

Figure 1. The sequence alignments for 15 HR-HPV subtypes (HPV16, 18, 31, 33, 35, 39, 45, 51, 52, 56, 58, 59, 68, 73, 82) and 9 LR-HPV subtypes (HPV6, 11, 40, 42, 43, 44, 54, 61, 81). Yellow highlights the targets of miR-875, red highlights the targets of miR3144 , orange show their overlapping districts. Blue shows the degree of conservation in each Nucleotide site. The more conserved it is, the darker blue it shows. Black columns at the bottom show the consensus of conservation in each Nucleotide site.

from two independent experiments, expressed as Renilla luciferase activity relative to that of control firefly luciferase, are shown in Fig. 2. In C33A cells, co-transfection with miR-
875 and its target (209-231) decreased the relative luciferase activity to $49 \%$ compared with empty pSilencer4.1CMV vector and target, and co-transfection with miR-3144 
Table 2. Sequences and names of constructed plasmids

\begin{tabular}{|c|c|c|c|}
\hline Name & Sequences & Vector & Constructed plasmids \\
\hline MiR-875 & UAUACCUCAGUUUUAUCAGGUG & pSilencer4.1-CMV & $\begin{array}{l}\text { MiR-875 } \\
\text { Expression vector }\end{array}$ \\
\hline Target: 209-231 nt* & CAGTTACTGCGACGTGAGGTATA & psiCheck-2 & $\begin{array}{l}\text { 209-231 } \\
\text { Luciferase reporter }\end{array}$ \\
\hline Mutated target & CAGTTACTGCGACGTGAGGATTA & psiCheck-2 & $\begin{array}{l}\Delta 209-231 \\
\text { Mutated reporter }\end{array}$ \\
\hline MiR-3144 & AUAUACCUGUUCGGUCUCUUUA & pSilencer4.1-CMV & $\begin{array}{l}\text { MiR-3144 } \\
\text { Expression vector }\end{array}$ \\
\hline Target: $207-232$ nt $^{*}$ & AACAGTTACTGCGACGTGAGGTATAT & psiCheck-2 & $\begin{array}{l}207-232 \\
\text { Luciferase reporter }\end{array}$ \\
\hline Mutated target & AACAGTTACTGCGACGTGAGGATTAT & psiCheck-2 & $\begin{array}{l}\Delta 207-232 \\
\text { Mutated reporter }\end{array}$ \\
\hline E6 & NC_001526, nt 83-559 (498bp) $)^{* *}$ & pcDNA3.1 & pcDNA3.1-E6 \\
\hline
\end{tabular}

* Sites in HPV16 genome.

** Sequence from HPV16 genome (NC_001526).
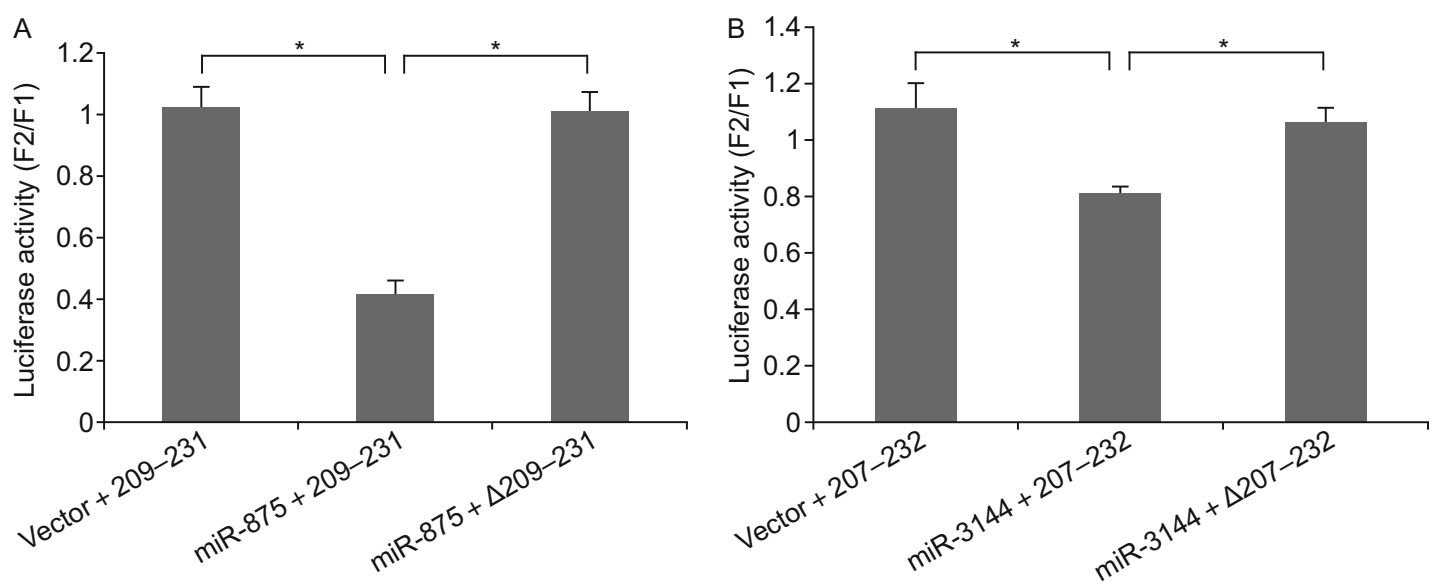

Figure 2. MiR-875 and miR-3144 inhibit luciferase reporter expression. (A) Analysis of the relative luciferase activity in C33A cells co-transfected with miR-875 vector and target (209-231) reporter, or empty vector and target (209-231) reporter, or miR-875 vector and mutated target $(\Delta 209-231)$ reporter. $(B)$ Analysis of the relative luciferase activity in C33A cells co-transfected with miR3144 vector and target (207-232) reporter, or empty vector and target (207-232) reporter, or miR-3144 vector and mutated target $(\Delta 207-232)$ reporter. $P$-values at Student's $t$-test were ${ }^{*} P<0.05$.

and its target (207-232) decreased the activity to $71 \%$ compared to empty vector and target. To examine whether the interaction between miRNAs and their target sequences direct or indirect, we mutated the miRNA binding sites with one or two nucleotide mutations (Table 2). As a result, with those mutation presented in reporter $(\Delta 209-231, \Delta 207-232)$, luciferase expression failed to be regulated by miR-875 and miR-3144 (Fig. 2). These experiments demonstrated that miR-875 and miR-3144 interacted directly with their binding sites to regulate luciferase reporter expression, and the effect was supposed to be highly specific, as it was abolished when the target sequence was single-nucleotide or two-nucleotide mutated.

\section{MiR-875 and miR-3144 negatively regulate exogenous E6 gene expression}

MiRNAs can suppress the expression of target genes through translational repression or through degradation of a target's transcript. Since miR-875 and miR-3144 can downregulate the luciferase expression by binding to their target in E6, we investigated whether the two miRNAs could directly 


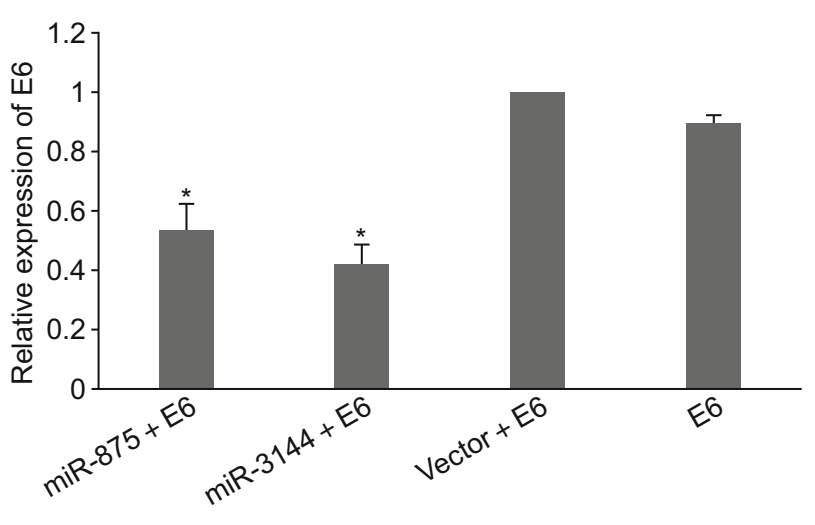

Figure 3. MiR-875 and miR-3144 decrease the expression of exogenous E6. The relative expression of E6 mRNA obtained by qRT-PCR in C33A cells after co-transfection with synthetically E6 construct along with miRNAs vectors or empty vector. $P$ values at Student's $t$-test were ${ }^{*} P<0.05$.

regulate E6 expression. We transfected synthetically E6 construct (pcDNA3.1-E6) into HPV-negative cervical carcinoma cell lines $(\mathrm{C} 33 \mathrm{~A})$. Although $\mathrm{E} 6$ gene is transcribed through bicistronic E6/E7 mRNA, studies show that transfection with monocistronic E6 into C33A cells could also result in a stable expression of unspliced E6 mRNA (del Moral-Hernandez et al., 2010). Some of these cells were then transfected with miRNAs expression vectors or empty pSilencer4.1-CMV vector. Then quantitative real-time RTPCR was used to quantitate the E6 mRNA level in all group cells. The results obtained from this experiment, expressed as relative expression normalized with internal control gene homo-Actin. As shown in Fig. 3, transfection with synthetically E6 construct (E6) or along with empty pSilencer4.1-CMV vector (vector + E6) result in stable expression of E6 mRNA, while transfection with E6 construct along with miR-875 (miR-875 + E6) or miR-3144 (miR$875+E 6)$ individually decreased the expression of E6 mRNA to $53 \%$ or $42 \%$.

\section{MiR-875 and miR-3144 negatively regulate endogenous E6 gene expression}

The experimental model above was used to measure the repression effect on exogenous $\mathrm{E} 6$, we further investigated whether miR-875 and miR-3144 could interfere with the expression of endogenous E6 oncogene. MiR-875 and miR3144 expression vectors were then transfected into cervical cancer SiHa cells which contain integrated HPV16 DNA and have detectable level of E6 oncogene mRNA (Rosenberger et al., 2010). Empty pSilencer4.1-CMV vector (Vector) and untreated $\mathrm{SiHa}$ cells (Mock) were used for controls. As shown in Fig. 4A, the expression levels of miR-875 and miR3144 in SiHa cells after transfection obtained by RT-qPCR were significantly increased compared to controls. The RTPCR was then used to detect the average cellular content of
E6 oncogene mRNA. As shown in Fig. 4B and 4C, transfection with miR-875 decreases the cellular content of E6 mRNA by $26.0 \%$ compared to Mock control and $26.4 \%$ to Vector control. Likewise, transfection with miR-3144 decreases the E6 mRNA by $30.5 \%$ compared to Mock control and $25.3 \%$ to Vector control. The regulation was believed to be remarkable if we consider the possible pre-existing expression of other endogenous targets of the two miRNAs, as one miRNA always target more than one gene. Taken together, these results indicated that miR-875 and miR-3144 negatively regulate not only exogenous E6 gene expression from synthetic construct but also endogenous E6 oncogene expression in an in vitro model through mRNA degradation.

High level of miR-875 and miR-3144 inhibit cell growth in SiHa cells

In order to detect the effect of increased level of miR-875 or miR-3144 on cancer cell growth, miR-875 and miR-3144 expression vectors were individually transfected into $\mathrm{SiHa}$ cells and the increased levels of the two miRNAs were confirmed by RT-qPCR as described previously. Untreated cells (Mock) and cells transfected with empty vector (Vector) were used for controls. The xCELLigence RTCA System was then performed to monitor the proliferative potential of those cells. In this system, the growth rate of cells was measured by monitoring the cell index which depend on the electronic readout of cell sensor impedance with real-time and continuous record every $4 \mathrm{~h}$. After $120 \mathrm{~h}$ of monitoring cell proliferation with this System, we observed a continuous decrease of cell growth and motility in both miR-875 transfected cells and miR-3144 transfected cells. Instead, those cells in two control groups continued to grow smoothly during this period (Fig. 5), suggesting that overexpression of miR-875 and miR3144 could inhibit the growth of cervical cancer cells.

\section{High level of miR-875 and miR-3144 induces apoptosis in SiHa cells}

In order to determine whether increased level of miR-875 or miR-3144 induce apoptosis of cervical cancer cell, flow cytometric analysis of cell apoptosis was performed for $\mathrm{SiHa}$ cells transfected with miR-875 or miR-3144 expression vectors, SiHa cells transfected with empty vectors (Vector) and untreated $\mathrm{SiHa}$ cells (Mock). As shown in Fig. 6A, SiHa cells in two control groups were primarily Annexin V/propidium iodide $(\mathrm{PI})$ negative and remained viable, but the $\mathrm{SiHa}$ cells with transfection of miR-875 and miR-3144 vectors were observed to undergo apoptosis in both early and late periods, which were shown by Annexin-V+/PI- for early apoptotic stage and annexin- $\mathrm{V}+/ \mathrm{PI}+$ for late apoptotic stage. And the rate of early apoptosis, late apoptosis and total apoptosis were calculated and shown in Fig. 6B. The results showed that overexpression of miR-875 and miR-3144 can significantly increase apoptosis in HPV-positive cervical cancer cells. 

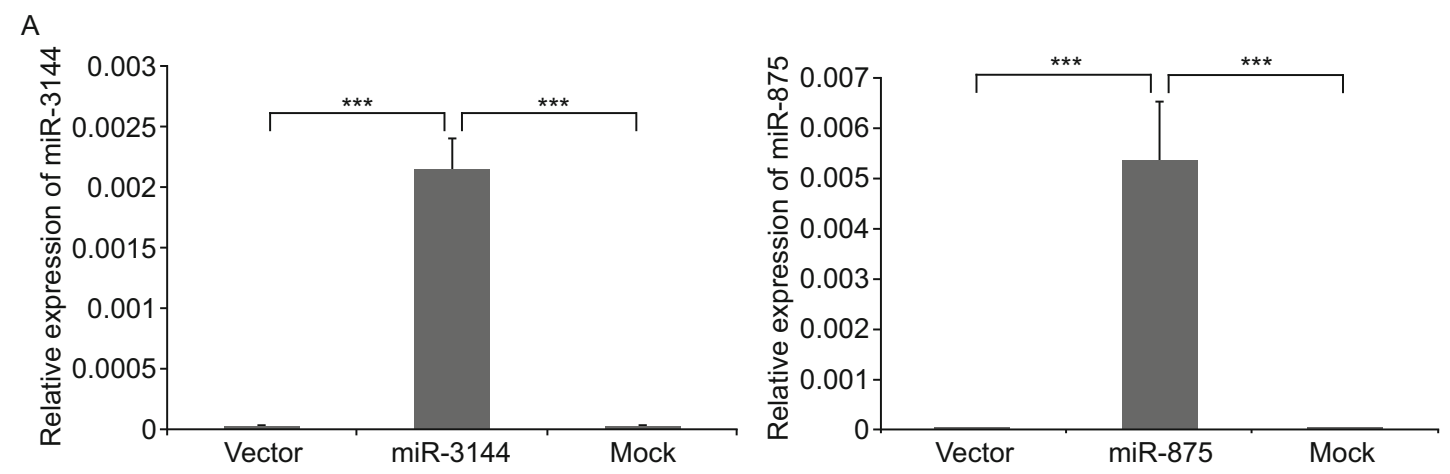

B
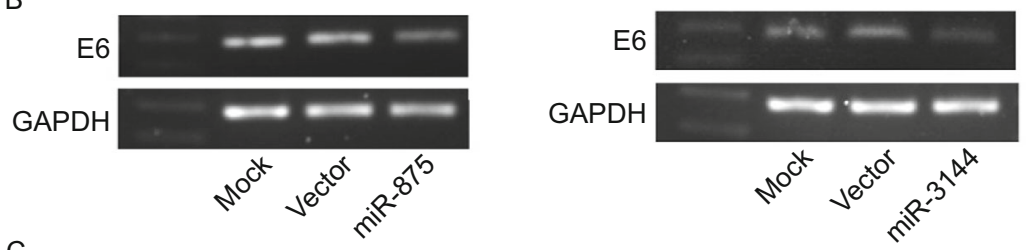

C
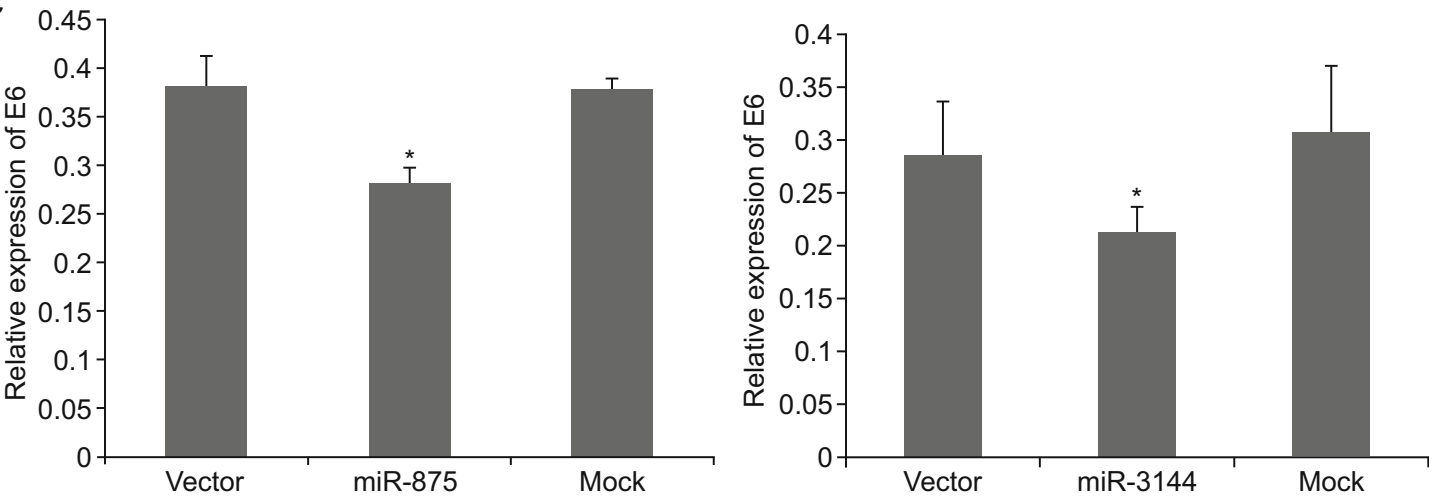

Figure 4. Transfection with miR-875 and miR-3144 interferes the expression of endogenous E6. (A) The expression levels of miR-875 or miR-3144 by qRT-PCR in SiHa cells transfected with miR-875 or miR-3144 expression vectors, SiHa cells transfected with empty vectors (Vector), or untreated SiHa cells (Mock). (B and C) RT-PCR analysis of E6 mRNA relative expression in SiHa cells transfected with miR-875 or miR-3144 expression vectors, SiHa cells transfected with empty vectors (Vector), or untreated SiHa cells (Mock). $P$-values at Student's $t$-test were ${ }^{*} P<0.05,{ }^{* \star *} P<0.001$.

The effects of overexpression of miR-875 and miR-3144 on nuclear morphology were measured by Hoechst 33258 staining, since the morphological changes in the nuclear chromatin is indicative of the apoptotic process. As shown in Fig. 7A, SiHa cells with transfection of miR-875 and miR3144 vectors exhibited reduced nuclear size, intense fluorescence, chromatin condensation, nuclear fragmentation, and presence of apoptotic bodies evident and were considered apoptotic cells. As shown in Fig. 7B, the percentage of cells with apoptotic morphology was significantly increased in with miR-875 and miR-3144 transfected cells, compared with cells in two control groups.

\section{DISCUSSION}

Cervical cancer, which is caused by persistent infection with high-risk HPVs, is the second most common type of cancer in women worldwide (Stewart and Wild, 2014). While recent reports have highlighted the role of miRNAs as critical effectors in intricate host-virus interaction networks, we address whether human miRNAs influence HPV oncogene in this study. We employed bioinformatics approaches scanning all potential targets of human miRNAs on 24 unambiguous risk-type HPVs. A well-conserved target site among most HR-HPVs of two candidate miRNAs, miR-875 and miR3144, has been found. By using the luciferase reporter, synthetically constructs and cultured cells, we show that miR-875 and miR-3144 can cause silencing effect of target reporter and interfere with the expression of E6 oncogene. In the presence of high-level miR-875 and miR-3144, HPVpositive cervical cancer cells undergo apparent growth retardation and apoptosis promotion.

The targets of miR-875 and miR-3144 were found located in encoding region of E6, which is the main oncogene 

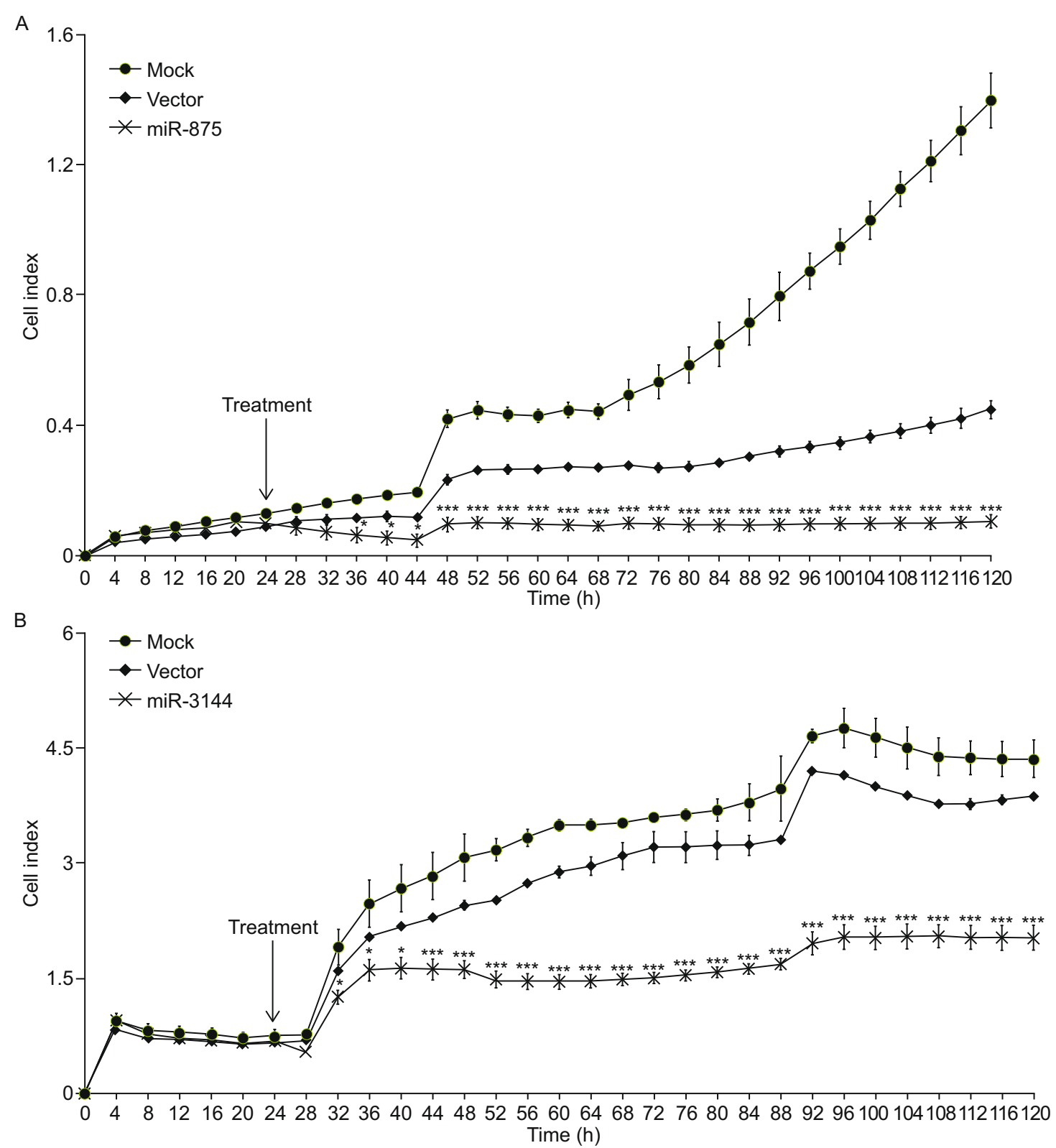

Figure 5. High-level of miR-875 and miR-3144 inhibit cell growth. Time kinetics of cell growth after $120 \mathrm{~h}$ of monitoring every $4 \mathrm{~h}$ with the XCELLigence RTCA DP System in SiHa cells transfected with miR-875 (A) or miR-3144 (B) vectors, or with empty vectors (Vector), or untreated SiHa cells (Mock). $P$-values at Student's $t$-test were ${ }^{*} P<0.05,{ }^{* * *} P<0.001$.

associated with oncogenicity of HR-HPVs. E6 oncoprotein was known to be able to directly target and degrade the tumor suppressor p53, therefore inhibit p53-mediated apoptosis, reduce p21-mediated cell cycle regulation, and destabilize chromosomes, favoring tumor progression of cervical cancer (Hausen, 2002). In this study, we demonstrated that miR-875 and miR-3144 could suppress the expression of both exogenous E6 and endogenous E6 by directly targeting E6 ORF. It should be noted that the first alternative exon of HR-HPV' early transcripts in E6 ORF region can be alternatively spliced and lead to at least four species of mRNA transcripts with various coding potential in HPV16 (5' splice site at $226 \mathrm{nt}$ and three alternative $3^{\prime}$ splice site at $409 \mathrm{nt}, 526 \mathrm{nt}$, or $742 \mathrm{nt}$ ) (Zheng and Baker, 2006). Among them, only un-spliced E6 full-length transcript encodes E6 oncoprotein and exhibit transforming capacity, whereas other spliced transcripts E6* counteract E6 oncoprotein functions (Filippova et al., 2007; Pim and Banks, 1999). The target sites of miR- 875 and miR-3144 in this study were found overlap to this alternative splice exon and thereby target only full-length transcript of E6 but no other spliced transcripts. Since the primers used for PCR in this 

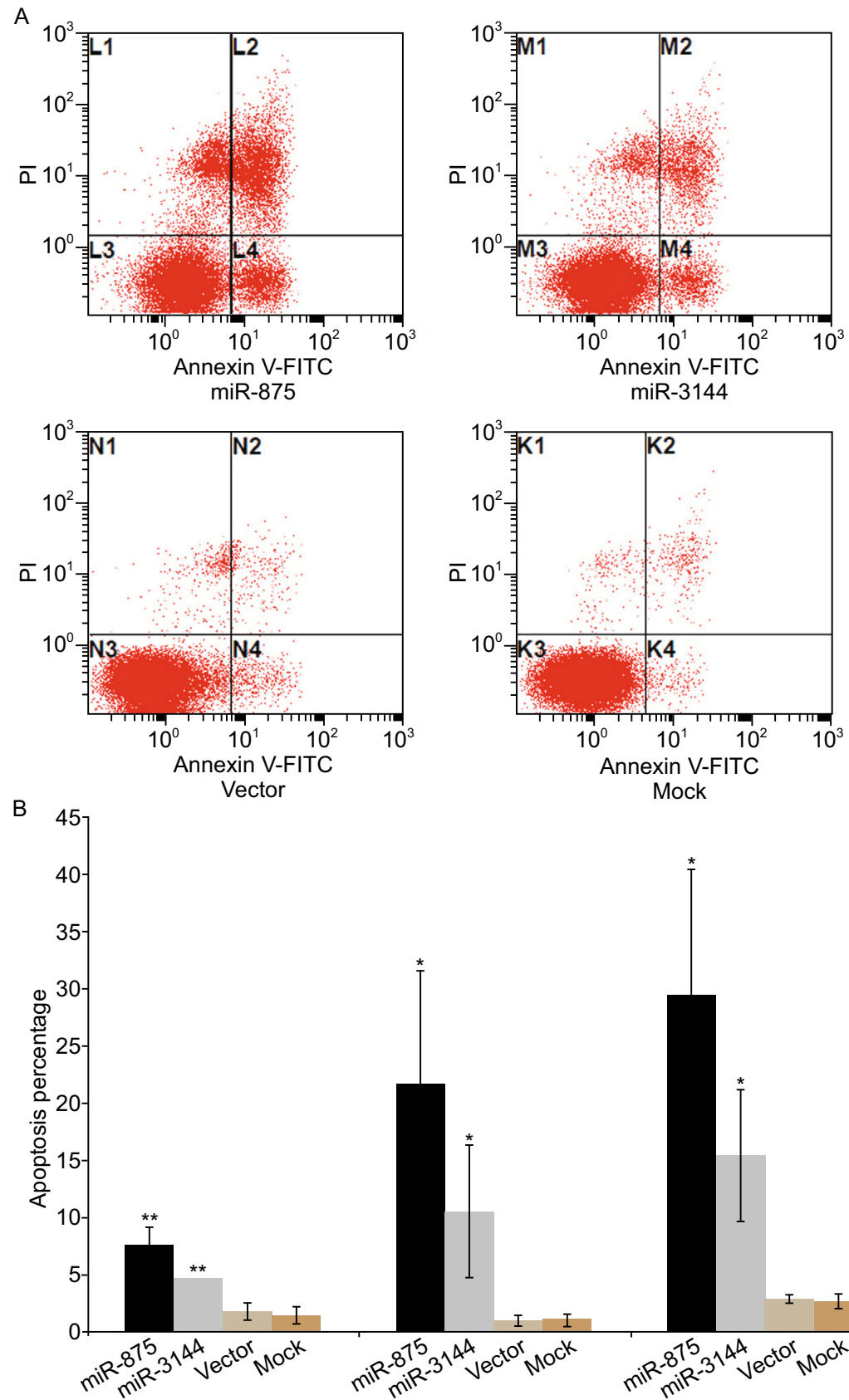

Early stage apoptosis

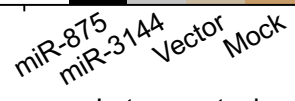

Late apoptosis

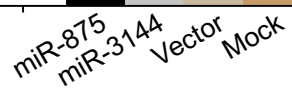

Total apoptosis

Figure 6. High-level of miR-875 and miR-3144 promoted cell apoptosis. (A) Annexin-V/PI analysis in SiHa cells transfected with miR-875 or miR-3144 vector, or with empty vectors (Vector), or untreated SiHa cells (Mock). (B) Early apoptosis, late apoptosis and the sum total of apoptosis in different group cells. $P$-values at Student's $t$-test were ${ }^{\star} P<0.05,{ }^{\star \star} P<0.01$.

study cover the $5^{\prime}$ splice site which only exists in un-spliced transcript of E6, our data support that miR-875 and miR-3144 interfere with expression of E6 full-length transcript, the latter was considered as the only source of the E6 oncoprotein (Stacey et al., 1995). Interestingly, alternatively spliced E6 transcripts have so far only been described for HR-HPVs but not for LR-HPVs (Hernandez-Lopez and Graham, 2012), implying that this region may have functional relevance on biological processes of HR-HPV carcinogenesis. Since we have little knowledge on the regulation of HPV at the level of RNA splicing (Zheng and Baker, 2006), whether the reason why the targets of miR-875 and miR-3144 precisely overlap to this region is a coincidence or that they are involved in regulation of alternative splicing is not yet known.

So far, little is known about the biological function of miR875 (located in Chr 8q22.2) and miR-3144 (located in Chr 
A

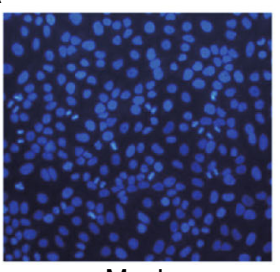

Mock

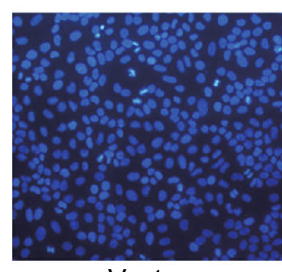

Vector

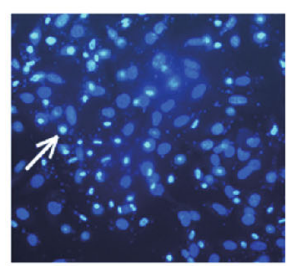

miR-875

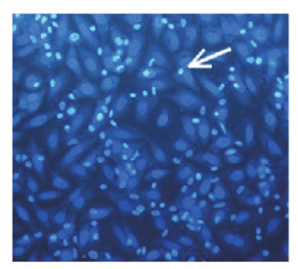

miR-3144

B

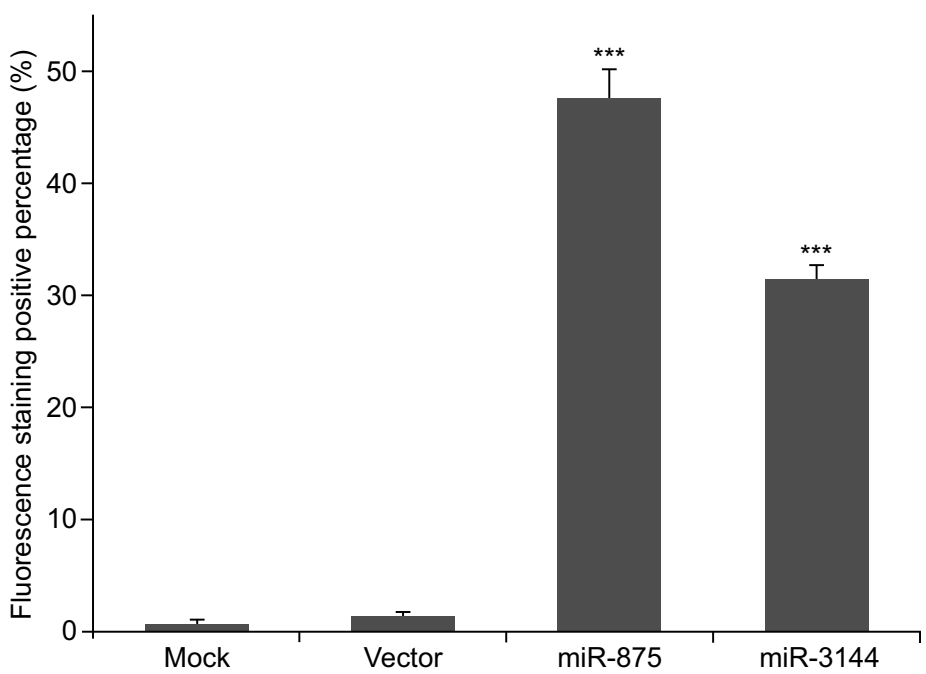

Figure 7. High-level of miR-875 and miR-3144 induced apoptotic morphological changes. (A) Apoptotic morphological changes (white arrows) with Hoechst staining (blue) in fluorescence microscope $(200 \times$ times) in SiHa cells transfected with miR-875 or miR3144 vector, or with empty vectors (Vector), or untreated SiHa cells (Mock). (B) Histograms for quantification of the cell death (\%) in different groups. $P$-values at Student's $t$-test were ${ }^{* \star *} P<0.001$.

6q22.31, a common fragile site in which HPV16 integration happens frequently) (Thorland et al., 2000; Zhao et al., 2012), which were first reported publicly in 2007 and 2010 respectively (Landgraf et al., 2007; Stark et al., 2010). Both of them have previously been reported by Daniela Witten and his colleagues to be expressed at rather low levels in human cervical tumor tissues, including squamous cell carcinoma tissue and adenosquamous cell carcinoma tissue, with median expression 1.5 reads observed for miR-875 and 1 reads observed for miR-3144 (Witten et al., 2010). Based on our observations, it is reasonable to explain that a suitable low level of miRNAs with antiviral effect is beneficial for HPV's survival and persistent latency favoring carcinogenesis. Moreover, miR-875 and miR-3144 have also been reported to be dysregulated in several types of cancer, such as pancreatic cancer, clear cell renal cell cancer, prostate cancer, colorectal cancer, and upper tract urothelial cancer (Hamfjord et al., 2012; Hao et al., 2011; Nguyen et al., 2013; Weng et al., 2010; Zaravinos et al., 2014). Similar to the present study, miR-875 was considered as one of the 14 candidate miRNAs which potentially target EGFR and act as the therapeutic target of lung cancer in Lawrence WC Chan's study (Chan et al., 2012), and miR-875 was also linked to cell apoptosis pathways in dopaminergic neuronal cells and severe H1N1 viral infected cells (Juan Moran, 2014; Li et al.,
2013). Taken together, although only a few studies have been done on the function of miR-875 and miR-3144, evidence regarding miR-875 or miR-3144 mediated tumor suppression is beginning to emerge.

However, the biological role of this effect on natural HPV carcinogenesis remains unclear. It may be insufficient to eliminate the viruses but only counteract viral replication to evade immune elimination and establish a persistent infection with a long host survival and a high spread of the virus in the human population, like HBV, HCV, and HIV-1 (Russo and Potenza, 2011). Therefore, forced high level of miR-875 and miR-3144 in HPV-positive cervical cancer cells as we show in this study could unbalance the HPV-host coexistence and may re-direct the outcome from a persistent HR-HPV infection to a complete recovery.

This study adds to the growing body of evidence implicating the association between miRNA and HPV in carcinogenesis. Aberrant cellular miRNAs expression profiles in HPVs infected cervical cancer tissue or cell have been reported (de Freitas et al., 2014). Several host miRNAs can be modulated by oncogenic HPVs (Greco et al., 2011; Martinez et al., 2008; Shi et al., 2012; Zheng and Wang, 2011). HPVs were found to encode their own miRNA species lately (Qian et al., 2013). However, limited investigations refer to the interplay between HPV genes and miRNAs. Until recently, 
some miRNAs were suggested to be involved in HPV regulation which were based on limited HPV subtypes, shown by that miR-203 have inhibitory effect on HPV16 DNA replication, miR-125b and miR-145 suppress HPV31 amplification, and miR-375 interact with E1 and E7 gene of HPV16 (Gunasekharan and Laimins, 2013; Jung et al., 2014; Melar-New and Laimins, 2010; Nuovo et al., 2010). This work provides two less common human miRNAs who can target HPV16 E6 oncogene which the target site is a promising common target for most HR-HPVs. So far, therapeutics for clearing persistent HR-HPV infection are still very limited (Harper and Demars, 2014). The optimal antiHPV strategy should be against multiple HR-HPV subtypes, since co-infection is rather common in cervical cancer (Mejlhede et al., 2010). Although this study is preliminary with only in vitro experiments, we believe the results add to the novel knowledge for anti-HPV strategies.

While the prevailing wisdom is that miRNAs bind to the 3'UTR of target genes, this study shows that miR-875 and miR-3144 bind to the coding region of E6. The possible explanation is that HPV genome is limited and $3^{\prime}$ UTR sequence is not long enough. Likewise, evidence in some other viruses, like $\mathrm{HBV}$ and $\mathrm{HCV}$, reveals that coding region or 5'UTR could be targeted by miRNAs (Li et al., 2011; Potenza et al., 2011). Moreover, our result is consistent with Anita Dreher's assumption that 3'UTR in HPV genome might be not a target for miRNA regulation (Dreher et al., 2011). Zheng et al. have hypothesized that several dozen potential miRNA binding sites exist in the genome-wide distribution of HPV (Harper and Demars, 2014), suggesting a need for further investigation to unveil more cellular miRNA-mediated regulation of HPV.

\section{MATERIALS AND METHODS}

Materials

The psiCheck-2 vector was purchased from Promega. The pSilencer4.1-CMV vector and pcDNA3.1 vector were obtained from Ambion. DNA oligonucleotides were obtained from Invitrogen. The HPV 16-positive SiHa cervical cancer cell line and HPV-negative C33A cervical cancer cell line were used in this study.

\section{Computational analyses}

The standard viral genome sequences were obtained from PaVE: Papilloma virus genome database (http://pave.niaid.nih.gov/). All human mature miRNA sequences were obtained from miRBase Release 14.0 (http://www.mirbase.org/) (Griffiths-Jones et al., 2008). Alignment of the DNA sequences of the viral genomes was performed with MUSCLE 3.6. The miRanda-3.3a was used to scan the HPV genomic sequence for the potential target sites for miRNAs (John et al., 2004). The modes of hybridization in computer programs were based on the principles of miRNA-target recognition containing the following parameters: complementarity on local base pairs, RNA-RNA double chain free energy, hybridization temperature, conservation of the site, and miRanda score (Bentwich, 2005).

\section{Plasmid constructs}

Nucleotide sequences of putative miRNAs binding sites in HPV were obtained by chemical synthesis of complementary oligonucleotides and were cloned into psiCheck-2 vectors at Xhol and Notl sites as luciferase reporter. The mutated target luciferase reporter bearing single-nucleotide or two-nucleotide mutated target sequences were obtained by the same approach. Human miRNA precursors were cloned into pSilencer4.1-CMV vectors at BamHI and Hindlll sites to construct miRNA expression vectors. A 498 bp fragment containing full-length E6 ORF of HPV16 (NC_001526, nt 83-559) were amplified by PCR and cloned into pcDNA3.1 vector at Nhel/Xhol sites, resulting in E6 construct named pcDNA3.1-E6. All the selected constructs were then sequenced to confirm their identity. Sequences and the names of constructed plasmids were showed as detailed in Table 2.

\section{Cell cultures and transfections}

SiHa cells and C-33A cells were cultured in DMEM with $10 \%$ fetal bovine serum at $37^{\circ} \mathrm{C}$ and $5 \% \mathrm{CO}_{2}$. Cells were washed with PBS and switched to antibiotic-free growth medium for $24-48 \mathrm{~h}$ before transfection. Transfections were performed with cells at $80 \%-90 \%$ of confluence by using of Lipofectamine 2000 (Invitrogen) according to the manufacturer's protocol.

To determine whether miRNAs could bind to their putative target sites in luciferase reporter, C33A cells were co-transfected with target luciferase reporter or mutated target reporter, and with matched miRNAs expression vector. The empty pSilencer4.1 vector was used as a negative control. After $24 \mathrm{~h}$, the cells were harvested for relative luciferase assay analysis.

To determine the effects of miRNAs on E6 expression from exogenous plasmids, C33A cells were co-transfected with pcDNA3.1E6 vector and miRNAs expression vector. The empty pSilencer4.1 vector was used as control. After $48 \mathrm{~h}$, the cells were collected and analyzed for E6 mRNA level by RT-PCR.

To determine the effects of miRNAs on endogenous E6 expression, HPV16-infected cervical cancer $\mathrm{SiHa}$ cells were transfected with miRNAs expression vector or empty pSilencer4.1 vector. Untreated $\mathrm{SiHa}$ cells were used as another control. After $48 \mathrm{~h}$, the cells were collected for RT-PCR analysis.

In order to determine whether miRNAs influence the proliferation and apoptosis of HPV infected cancer cells, SiHa cells were transfected with miRNAs expression vector or empty pSilencer4. 1 vector. Untreated $\mathrm{SiHa}$ cells were used as another control. The cells were collected for Real time cell analysis (RTCA), Annexin V assay and Hoechst staining assay.

\section{Luciferase report assays}

Luciferase assays were performed $24 \mathrm{~h}$ after transfection of C33A cells using the Dual-Luciferase Reporter Assay System (Promega) following the manufacturer's instructions. The mean of the luciferase activities measured with Luminoskan TL Plus luminometer (Thermo Labsystems) were used to calculate ratios between Renilla lucsiferase (F2) and firefly luciferases (F1). 
Table 3. Primers used in this study

\begin{tabular}{|c|c|c|c|}
\hline Target & Primer name & Primer sequence $\left(5^{\prime}\right.$ to $\left.3^{\prime}\right)$ & Application \\
\hline \multirow[t]{2}{*}{ E6 } & E6-F & AGCGACCCAGAAAGTTACCA & \multirow[t]{2}{*}{ QPCR } \\
\hline & E6-R & GCATAAATCCCGAAAAGCAA & \\
\hline \multirow[t]{2}{*}{ E6 } & Q-E6-F2 (QP357) & AGCGACCCAGAAAGTTACCA & \multirow[t]{2}{*}{ RT-PCR } \\
\hline & Q-E6-R2 (QP358) & AATTCCTAGTGTGCCCATTAAC & \\
\hline \multirow[t]{2}{*}{ MiR-3144 } & Q-miR-3144-RT & $\begin{array}{l}\text { CTCAACTGGTGTCGTGGAGTCGGCAA } \\
\text { TTCAGTTGAGCTATATAT }\end{array}$ & $\mathrm{RT}$ \\
\hline & Q-miR-3144-F & АCACTCCAGCTGGGAGGGGACCAAAGAGAT & QPCR \\
\hline \multirow[t]{2}{*}{ MiR-875 } & Q-miR-875-RT & $\begin{array}{l}\text { CTCAACTGGTGTCGTGGAGTCGGCAATTCA } \\
\text { GTTGAGCACCTGAT }\end{array}$ & RT \\
\hline & Q-miR-875-F & ACACTCCAGCTGGGTATACCTCAGTTTTAT & QPCR \\
\hline \multirow[t]{2}{*}{ U6 } & U6-RT & CGCTTCACGAATTTGCGTGTCAT & RT \\
\hline & U6-F & GCTTCGGCAGCACATATACTAAAAT & QPCR \\
\hline Downstream universal primer & MiR-R & CGCTTCACGAATTTGCGTGTCAT & QPCR \\
\hline
\end{tabular}

\section{Quantitative real-time RT-PCR}

Total RNA was extracted from cultured cells using Trizol Reagent (Invitrogen) following the manufacturer's instructions. For miRNA analysis, mature miRNAs were reverse transcribed from total RNA using specific stem-loop RT primers. Per $15 \mu \mathrm{L}$ RT reaction included: 5× M-MLV buffer, dNTP, M-MLV (200 U), RNase inhibitor (40, specific stem-loop RT primers $(5 \mu \mathrm{mol} / \mathrm{L})$, total RNA $(1 \mu \mathrm{g})$ and $\mathrm{H}_{2} \mathrm{O}$. The mix then incubated at $16^{\circ} \mathrm{C}$ for $30 \mathrm{~min}, 42^{\circ} \mathrm{C}$ for $30 \mathrm{~min}, 85^{\circ} \mathrm{C}$ for $5 \mathrm{~min}$, at last the product chilled on ice for $5 \mathrm{~min}$.

For $\mathrm{E} 6$ analysis, $1 \mu \mathrm{g}$ RNA was diluted in $\mathrm{H}_{2} \mathrm{O}$ along with $1 \mu \mathrm{L}$ of Oligo dT Primer (Invitrogen) to obtain a total volume of $12 \mu \mathrm{L}$. Samples were incubated at $65^{\circ} \mathrm{C}$ for $5 \mathrm{~min}$ and chilled on ice for $3 \mathrm{~min}$. Then, $1 \mu \mathrm{L}$ of RNaseout (Invitrogen), $2 \mu \mathrm{L} 0.1 \mathrm{~mol} / \mathrm{L} \mathrm{dTT}$ (Invitrogen), and $4 \mu \mathrm{L} 5 \times$ First Strand Buffer (Invitrogen) were added and samples were then incubated at $25^{\circ} \mathrm{C}$ for $10 \mathrm{~min}$.

Real-time PCR apparatus (CFX96, Bio-Rad), associated with CFX Manager Software (version 1.6, Bio-Rad), was used for the real-time PCR. Each reaction was done in duplicate in a volume of $20 \mu \mathrm{L}$ with 96-well optical-grade PCR plates, sealed with optical sealing tape (Bio-Rad). Amplification reactions were done with SYBR Green Supermix (Bio-Rad) and following temperature profiles: one cycle at $95^{\circ} \mathrm{C}$ ( $3 \mathrm{~min}$ ), 40 cycles of denaturation at $95^{\circ} \mathrm{C}$ (30 s), annealing at $60^{\circ} \mathrm{C}(30 \mathrm{~s})$, extension at $72^{\circ} \mathrm{C}(30 \mathrm{~s})$ and one final cycle at $95^{\circ} \mathrm{C}(30 \mathrm{~s})$. Melt curve analyses were performed by slowly heating the PCR mixtures from $65^{\circ} \mathrm{C}$ to $95^{\circ} \mathrm{C}\left(1^{\circ} \mathrm{C}\right.$ per cycle of $10 \mathrm{~s}$ ) with simultaneous measurements of the SYBR Green I signal intensities. Relative expressions were calculated by the formula $2^{-\Delta \Delta \mathrm{Ct}}$.

For semi-quantitative PCR, cDNA was diluted 1:40 in $\mathrm{H}_{2} \mathrm{O}$ and $1 \mu \mathrm{L}$ were amplified in $20 \mu \mathrm{L}$ with $2 \times$ PCR Master Mix using $1 \mu \mathrm{L}$ of a $10 \mu \mathrm{mol} / \mathrm{L}$ primer mix. The $\mathrm{PCR}$ reaction was conducted at $95^{\circ} \mathrm{C}$ for $3 \mathrm{~min}$, followed by 30 cycles of $95^{\circ} \mathrm{C}$ for $10 \mathrm{~s}, 60^{\circ} \mathrm{C}$ for $30 \mathrm{~s}$ and $72^{\circ} \mathrm{C}$ for $1 \mathrm{~min}$. The intensities of products obtained were measured by TotalLab100 software. Primers used in this study were shown in Table 3.

\section{Real time cell analysis (RTCA)}

In order to measure the proliferative potential of cells, SiHa cells were seeded in a density of $1-2 \times 10^{5}$ cells/well in E-plate according to the manufacturer's instructions and were monitored every $4 \mathrm{~h}$ using a real time cell analyzer (RTCA, xCELLigence, Roche). In this system, cells adhere to the bottom of each well, covering the surface of the sensor that monitors cells by measuring their cell index that is translated from the electronic readout. The cell growth curves were recorded for $120 \mathrm{~h}$ to assess the capability of cell proliferation.

\section{Flow cytometric analysis of cell apoptosis}

In order to quantify early apoptosis and late apoptosis induced by miRNAs, cell apoptosis was measured using the Annexin V Apoptosis Detection Kit according to the manufacturer's protocol. Briefly, at $24 \mathrm{~h}$ after transfection with vectors, $\mathrm{SiHa}$ cells were trypsinized and washed with cold PBS, and then resuspended in $100 \mu \mathrm{L} 1 \times$ binding buffer at $1 \times 10^{6}$ cells $/ \mathrm{mL}$. $100 \mu \mathrm{L}$ of cells were then added with $5 \mu \mathrm{L}$ of Annexin $V$ and $1 \mu \mathrm{L}$ of propidium iodide (PI) and were incubated for $15 \mathrm{~min}$ at room temperature in the dark. After incubation, $400 \mu \mathrm{L} 1 \times$ binding buffer was added to each tube, and the samples were analyzed by flow cytometry (Beckman-Coulter) within $1 \mathrm{~h}$.

\section{Hoechst staining assay}

In order to examine the nuclear morphological changes in cells, cells were stained with Hoechst 33258 , and visualized by fluorescence microscope according to the manufacturer's protocol. Briefly, $\mathrm{SiHa}$ cells were plated with $2.5 \times 10^{6}$ cells $/ \mathrm{mL}$ in 6 -well plates. At $24 \mathrm{~h}$ after transfection, cells were then collected by centrifugation, washed with phosphate buffered saline (PBS), fixed with paraformaldehyde and stained with $0.5 \mathrm{~mL}(10 \mu \mathrm{g} / \mathrm{mL})$ Hoechst 33258 in darkness for $5 \mathrm{~min}$ at room temperature. The results were observed and recorded under a fluorescence microscope. These cells exhibited reduced nuclear size, intense fluorescence, 
chromatin condensation, and nuclear fragmentation, were considered apoptotic cells. The percentage of Hoechst-positive apoptotic cells per visual field was determined.

\section{Statistical analysis}

All experiments were performed in triplicate in three independent experiments. The data were tested for significance employing the $t$-test and presented as mean \pm SD. The level of significance was set at $P<0.05$.

\section{ACKNOWLEDGEMENTS}

We would like to extend our sincere gratitude to Dr. James Crabbe for his help in editing the manuscript. This work was supported by the National Natural Science Foundation of China (Grant No. 81101955); and the Research Fund for the Doctoral Program of Higher Education of China (Grant No. 20110071120094).

\section{ABBREVIATIONS}

3'UTR, 3' untranslated region; 5'UTR, 5' untranslated region; Chr, chromosome; DMEM, dulbecco's modified eagle medium; EGFR, epidermal growth factor receptor; H5N1, human avian influenza $A$; $\mathrm{H} 1 \mathrm{~N} 1$, human pandemic influenza $A$; HBV, hepatitis B virus; $\mathrm{HCV}$, hepatitis $C$ virus; HIV, human immunodeficiency virus; HPV, human papillomaviruses; HR, high-risk; LR, low-risk; miRNA, microRNAs; MUSCLE, multiple sequence comparison by log-expectation; ORF, open reading frame; PBS, phosphate buffered saline; PFV-1, primate foamy virus type 1; PI, propidium iodide; RTCA, Real time cell analysis; URR, upper regulatory region.

\section{COMPLIANCE WITH ETHICS GUIDELINES}

Lin Lin, Qingqing Cai, Xiaoyan Zhang, Hongwei Zhang, Yang Zhong, Congjian $\mathrm{Xu}$, and Yanyun $\mathrm{Li}$ declare that they have no conflict of interest. This article does not contain any studies with human or animal subjects performed by the any of the authors.

\section{OPEN ACCESS}

This article is distributed under the terms of the Creative Commons Attribution License which permits any use, distribution, and reproduction in any medium, provided the original author(s) and the source are credited.

\section{REFERENCES}

Alp Avci G (2012) Genomic organization and proteins of human papillomavirus. Mikrobiyol bul 46:507-515

Ambros V (2004) The functions of animal microRNAs. Nature 431:350-355

Bentwich I (2005) Prediction and validation of microRNAs and their targets. FEBS Lett 579:5904-5910

Bernard HU, Burk RD, Chen Z, van Doorslaer K, zur Hausen H, de Villiers EM (2010)Classification of papillomaviruses (PVs) based on
189 PV types and proposal of taxonomic amendments. Virology 401:70-79

Chan LW, Wang FF, Cho WC (2012) Genomic sequence analysis of EGFR regulation by microRNAs in lung cancer. Curr Top Med Chem 12:920-926

de Freitas AC, Coimbra EC, Leitao Mda C (2014) Molecular targets of HPV oncoproteins: potential biomarkers for cervical carcinogenesis. Biochim Biophys Acta 1845:91-103

del Moral-Hernandez O, Lopez-Urrutia E, Bonilla-Moreno R, Martinez-Salazar M, Arechaga-Ocampo E, Berumen J, VillegasSepulveda N (2010) The HPV-16 E7 oncoprotein is expressed mainly from the unspliced E6/E7 transcript in cervical carcinoma C33-A cells. Arch Virol 155:1959-1970

Dreher A, Rossing M, Kaczkowski B, Andersen DK, Larsen TJ, Christophersen MK, Nielsen FC, Norrild B (2011) Differential expression of cellular microRNAs in HPV 11, -16, and -45 transfected cells. Biochem Biophys Res Commun 412:20-25

Filippova M, Johnson MM, Bautista M, Filippov V, Fodor N, Tungteakkhun SS, Williams K, Duerksen-Hughes PJ (2007) The large and small isoforms of human papillomavirus type 16 E6 bind to and differentially affect procaspase 8 stability and activity. J Virol 81:4116-4129

Forman JJ, Coller HA (2010) The code within the code: microRNAs target coding regions. Cell Cycle 9:1533-1541

Ghosh Z, Mallick B, Chakrabarti J (2009) Cellular versus viral microRNAs in host-virus interaction. Nucleic Acids Res 37:10351048

Greco D, Kivi N, Qian K, Leivonen SK, Auvinen P, Auvinen E (2011) Human papillomavirus 16 E5 modulates the expression of host microRNAs. PLoS One 6:e21646

Griffiths-Jones S, Saini HK, van Dongen S, Enright AJ (2008) miRBase: tools for microRNA genomics. Nucleic Acids Res 36 : D154-D158

Gunasekharan V, Laimins LA (2013) Human papillomaviruses modulate microRNA 145 expression to directly control genome amplification. J Virol 87:6037-6043

Hamfjord J, Stangeland AM, Hughes T, Skrede ML, Tveit KM, Ikdahl T, Kure EH (2012) Differential expression of miRNAs in colorectal cancer: comparison of paired tumor tissue and adjacent normal mucosa using high-throughput sequencing. PLoS One 7:e34150

Hao J, Zhang S, Zhou Y, Hu X, Shao C (2011) MicroRNA 483-3p suppresses the expression of DPC4/Smad4 in pancreatic cancer. FEBS Lett 585:207-213

Harper DM, Demars LR (2014) Primary strategies for HPV infection and cervical cancer prevention. Clin Obstet Gynecol 57:256-278

Hayes J, Peruzzi PP, Lawler S (2014) MicroRNAs in cancer: biomarkers, functions and therapy. Trends Mol Med 20:460-469

Hernandez-Lopez HR, Graham SV (2012) Alternative splicing in human tumour viruses: a therapeutic target? Biochem J 445:145156

Houzet L, Klase Z, Yeung ML, Wu A, Le SY, Quinones M, Jeang KT (2012) The extent of sequence complementarity correlates with the potency of cellular miRNA-mediated restriction of HIV-1. Nucleic Acids Res 40:11684-11696

Jimenez-Wences H, Peralta-Zaragoza O, Fernandez-Tilapa G (2014) Human papilloma virus, DNA methylation and microRNA 
expression in cervical cancer (Review). Oncol Rep 31:24672476

John B, Enright AJ, Aravin A, Tuschl T, Sander C, Marks DS (2004) Human microRNA targets. PLoS Biol 2:e363

Juan Moran GR, Uribe-Boll Jimena, Cruz Alfredo, Jimenez Luis, Banales Jose-Luis, Romero Sandra, Hidalgo Alfredo, Bautista Edgar, Merino Enrique, Zuniga Joaquin (2014) Circulating microRNA profiles in patients with severe pneumonia associated to the A/H1N1 virus. Am J Respir Crit Care Med 189:A2694

Jung HM, Phillips BL, Chan EK (2014) miR-375 activates p21 and suppresses telomerase activity by coordinately regulating HPV E6/E7, E6AP, CIP2A, and 14-3-3zeta. Mol Cancer 13:80

Kuhn DE, Martin MM, Feldman DS, Terry AV Jr, Nuovo GJ, Elton TS (2008) Experimental validation of miRNA targets. Methods 44:47-54

Landgraf $P$, Rusu $M$, Sheridan R, Sewer A, lovino N, Aravin A, Pfeffer S, Rice A, Kamphorst AO, Landthaler $M$ et al (2007) A mammalian microRNA expression atlas based on small RNA library sequencing. Cell 129:1401-1414

Lecellier $\mathrm{CH}$, Dunoyer P, Arar K, Lehmann-Che J, Eyquem S, Himber C, Saib A, Voinnet O (2005) A cellular microRNA mediates antiviral defense in human cells. Science 308:557-560

Li Y, Li Z, He Y, Kang Y, Zhang X, Cheng M, Zhong Y, Xu C (2009) Phylogeographic analysis of human papillomavirus 58 . Sci China Ser C 52:1164-1172

Li YP, Gottwein JM, Scheel TK, Jensen TB, Bukh J (2011) MicroRNA-122 antagonism against hepatitis $C$ virus genotypes 1-6 and reduced efficacy by host RNA insertion or mutations in the HCV 5' UTR. Proc Natl Acad Sci U S Am 108:4991-4996

Li L, Chen HZ, Chen FF, Li F, Wang M, Wang L, Li YQ, Gao DS (2013) Global microRNA expression profiling reveals differential expression of target genes in 6-hydroxydopamine-injured MN9D cells. Neuromol Med 15:593-604

Mahajan VS, Drake A, Chen J (2009) Virus-specific host miRNAs: antiviral defenses or promoters of persistent infection? Trends Immunol 30:1-7

Martinez I, Gardiner AS, Board KF, Monzon FA, Edwards RP, Khan SA (2008) Human papillomavirus type 16 reduces the expression of microRNA-218 in cervical carcinoma cells. Oncogene 27:2575-2582

Mejlhede N, Pedersen BV, Frisch M, Fomsgaard A (2010) Multiple human papilloma virus types in cervical infections: competition or synergy? APMIS 118:346-352

Melar-New M, Laimins LA (2010) Human papillomaviruses modulate expression of microRNA 203 upon epithelial differentiation to control levels of p63 proteins. J Virol 84:5212-5221

Munoz N, Bosch FX, de Sanjose S, Herrero R, Castellsague X, Shah KV, Snijders PJ, Meijer CJ, International Agency for Research on Cancer Multicenter Cervical Cancer Study, G (2003) Epidemiologic classification of human papillomavirus types associated with cervical cancer. N Engl J Med 348:518527

Nguyen HC, Xie W, Yang M, Hsieh CL, Drouin S, Lee GS, Kantoff PW (2013) Expression differences of circulating microRNAs in metastatic castration resistant prostate cancer and low-risk, localized prostate cancer. Prostate 73:346-354
Nuovo GJ, Wu X, Volinia S, Yan F, di Leva G, Chin N, Nicol AF, Jiang J, Otterson G, Schmittgen TD et al (2010) Strong inverse correlation between microRNA-125b and human papillomavirus DNA in productive infection. Diagn Mol Pathol 19:135-143

Pedersen IM, Cheng G, Wieland S, Volinia S, Croce CM, Chisari FV, David M (2007) Interferon modulation of cellular microRNAs as an antiviral mechanism. Nature 449:919-922

Pim D, Banks L (1999) HPV-18 E6*I protein modulates the E6directed degradation of $p 53$ by binding to full-length HPV-18 E6. Oncogene 18:7403-7408

Potenza N, Papa U, Mosca N, Zerbini F, Nobile V, Russo A (2011) Human microRNA hsa-miR-125a-5p interferes with expression of hepatitis B virus surface antigen. Nucleic Acids Res 39:51575163

Qian K, Pietila T, Ronty M, Michon F, Frilander MJ, Ritari J, Tarkkanen J, Paulin L, Auvinen P, Auvinen E (2013) Identification and validation of human papillomavirus encoded microRNAs. PLoS One 8:e70202

Qingqing Cai X.Z, Zoufeng Li (2010) MiRNAs as promising phylogenetic markers for inferring deep metazoan phylogeny and in support of Olfactores hypothesis. Bioinformatics and Biomedicine (BIBM), 2010 IEEE International Conference on 18-21 Dec 2010, Hong Kong, 101-104

Rosenberger S, De-Castro Arce J, Langbein L, Steenbergen RD, Rosl F (2010) Alternative splicing of human papillomavirus type16 E6/E6* early mRNA is coupled to EGF signaling via Erk $1 / 2$ activation. Proc Natl Acad Sci U S A 107:7006-7011

Russo A, Potenza N (2011) Antiviral effects of human microRNAs and conservation of their target sites. FEBS lett 585:2551-2555

Scaria V, Hariharan M, Maiti S, Pillai B, Brahmachari SK (2006) Host-virus interaction: a new role for microRNAs. Retrovirology 3:68

Scheffner M, Werness BA, Huibregtse JM, Levine AJ, Howley PM (1990) The E6 oncoprotein encoded by human papillomavirus types 16 and 18 promotes the degradation of p53. Cell 63:11291136

Shi M, Du L, Liu D, Qian L, Hu M, Yu M, Yang Z, Zhao M, Chen C, Guo L et al (2012) Glucocorticoid regulation of a novel HPV-E6p53-miR-145 pathway modulates invasion and therapy resistance of cervical cancer cells. J Pathol 228:148-157

Song L, Liu H, Gao S, Jiang W, Huang W (2010) Cellular microRNAs inhibit replication of the H1N1 influenza $A$ virus in infected cells. $J$ Virol 84:8849-8860

Stacey SN, Jordan D, Snijders PJ, Mackett M, Walboomers JM, Arrand JR (1995) Translation of the human papillomavirus type 16 E7 oncoprotein from bicistronic mRNA is independent of splicing events within the E6 open reading frame. J Virol 69:7023-7031

Stark MS, Tyagi S, Nancarrow DJ, Boyle GM, Cook AL, Whiteman DC, Parsons PG, Schmidt C, Sturm RA, Hayward NK (2010) Characterization of the melanoma miRNAome by deep sequencing. Plos One 5:e9685

Stewart BW, Wild CP (2014) World cancer report. IARC Scientific Publications, New Delhi

Thorland EC, Myers SL, Persing DH, Sarkar G, McGovern RM, Gostout BS, Smith DI (2000) Human papillomavirus type 16 
integrations in cervical tumors frequently occur in common fragile sites. Cancer Res 60:5916-5921

Weng L, Wu X, Gao H, Mu B, Li X, Wang JH, Guo C, Jin JM, Chen Z, Covarrubias $M$ et al (2010) MicroRNA profiling of clear cell renal cell carcinoma by whole-genome small RNA deep sequencing of paired frozen and formalin-fixed, paraffin-embedded tissue specimens. J Pathol 222:41-51

Witten D, Tibshirani R, Gu SG, Fire A, Lui WO (2010) Ultra-high throughput sequencing-based small RNA discovery and discrete statistical biomarker analysis in a collection of cervical tumours and matched controls. BMC Biol 8:58

Zaravinos A, Lambrou GI, Mourmouras N, Katafygiotis P, Papagregoriou G, Giannikou K, Delakas D, Deltas C (2014) New miRNA profiles accurately distinguish renal cell carcinomas and upper tract urothelial carcinomas from the normal kidney. PLoS One 9: e91646

Zhao X, Liu Q, Cai Q, Li Y, Xu C, Li Z, Zhang X (2012) Dr.VIS: a database of human disease-related viral integration sites. Nucleic Acids Res 40:D1041-D1046

Zheng ZM, Baker CC (2006) Papillomavirus genome structure, expression, and post-transcriptional regulation. Front Biosci 11:2286-2302

Zheng ZM, Wang X (2011) Regulation of cellular miRNA expression by human papillomaviruses. Biochim Biophys Acta 1809:668677

zur Hausen H (2002) Papillomaviruses and cancer: from basic studies to clinical application. Nat Rev Cancer 2:342-350 